Reprod. Nutr. Dévelop., 1986, 26 (1 A), 31-38.

\title{
Relationship between plasma glucagon disappearance and tissue uptake in rats
}

\author{
Michèle BALAGE, J. GRIZARD
}

with the collaboration of Marie-Louise HOULIER, A. SELLE and M. SALLAS

Laboratoire d'Etude du Métabolisme azoté (UA CNRS 041123),

I.N.R.A., Theix, 63122 Ceyrat, France.

\begin{abstract}
Summary. The fate of plasma glucagon has been analyzed in detail by Desbuquois and Postel-Vinay. The present work was carried out to clarify the relationships between plasma glucagon disappearance and its tissue uptake. For the purpose, we injected rats intravenously with ${ }^{125} \mathrm{f}$-glucagon alone or with concomitant or sequential injections of native glucagon. Plasma ${ }^{125} \mathrm{I}$-glucagon was analyzed by Biogel P10 chromatography. Liver and kidney glucagon kinetics were studied from the point of view of the evolution of the total radioactivity present in each tissue a few minutes after glucagon injection. ${ }^{125}$-glucagon was rapidly cleared from the plasma (half-life within $2 \mathrm{~min}$ ); it was intensively associated with liver and kidneys. Liver radioactivity rapidly declined within the first $5 \mathrm{~min}$ after injection, whereas kidney radioactivity increased. The concomitant injection of increasing amounts of native glucagon with ${ }^{125} \mathrm{I}$-glucagon progressively reduced the liver radioactivity, indicating that glucagon was trapped in a saturable compartment. In contrast, kidney radioactivity remained unchanged. The sequential injection of ${ }^{125} \mathrm{I}$-glucagon and excess native glucagon resulted in a shift to the right in the plasma ${ }^{125}$-glucagon decay curve which suggests that the glucagon excess displaced ${ }^{125} \mathrm{I}$-glucagon from its distribution compartment back into the plasma. The compartment where glucagon uptake occurred a few minutes after ${ }^{125} \mathrm{I}$-glucagon injection displayed some of the fundamental properties of glucagon receptors, i.e. saturatibility and reversibility.
\end{abstract}

\section{Introduction.}

Target cell binding is generally believed to be the first step in the mechanism of polypeptide hormone action (Roth, 1973). This assumption has been extensively investigated for insulin and glucagon using almost exclusively in vitro systems, such as isolated hepatocytes (Freychet et al., 1974 ; Gill and Hart, 1980 ; Fehlmann et al., 1981 ; Morin, Fehlmann and Freychet, 1982), adipocytes (Bataille, Freychet and Rosselin, 1974; Cuatrecasas, 1971) and purified liver plasma membranes (Rodbell et al., 1971 ; Bataille, Freychet and Rosselin, 1974 ; Giorgio, Johnson and Blecher, 1974 ; Cuatrecasas, Desbuquois and Krug, 1971). With insulin, Zeleznick and Roth (1978) demonstrated that a receptor compartment may be examined in vivo following hormone injection. This

Reproduction Nutrition Développement, $n^{\circ}$ I A-86. -3 
compartment, characterized by a high hormone turnover rate and in equilibrium with plasma hormone levels, is partly located in the liver (Bergeron and Posner, 1979 ; Sodoyez, Sodoyez-Goffaux and Moris, 1980a, 1980b. Gagliardino et al., 1980). There are however a few experiments concerning the fate of plasma glucagon. Desbuquois and Postel-Vinay (1980) investigated the distribution of labelled material in subcellular liver fractions following intravenous injection of 125|glucagon in rats. They observed that glucagon initially bound to plasma membranes and was progressively translocated within the cell where it associated with " Golgi » fractions. Barazzone et al. (1980) demonstrated that glucagon was located in lysosomal structures in isolated rat hepatocytes.

To our knowledge, there has been no study concerning the relationships between plasma glucagon and tissue uptake of glucagon in vivo as has been performed with insulin (Sodoyez, Sodoyez-Goffaux and Moris, 1980a). For this purpose we followed the fate of radioactivity in the plasma, liver and kidneys after intravenous injection of ${ }^{125} \mathrm{I}$-glucagon alone or with concomitant or sequential injections of native glucagon.

\section{Material and Methods.}

Chemicals. - Native glucagon, a crystalline glucagon purchased from the Sigma Chemical Company (USA), was used for native glucagon injections.

125]-monoiodoglucagon, a highly purified porcine glucagon (Novo Research Institute, Bagswaerd, Denmark ; G501575 $\mathrm{n}^{\circ}$ 6920101, $1.07 \mathrm{iu} / \mathrm{mg}$ ), was labelled with $\mathrm{Na}^{125}$ (IMS 30, Radiochemical Center, Amersham, England) by the choramin-T method (Freychet et al., 1971). The monoiodinated derivative was purified by DEAE cellulose chromatography (Nottey and Rosselin, 1971). The preparation contained approximately $30 \%$ 125I-monoiodoglucagon and $70 \%$ unlabelled hormone since the average specific activity was within $200 \mu \mathrm{Ci} / \mu \mathrm{g}$. It was verified that the iodinated glucagon interacted with liver plasma membranes to the same extent as native glucagon (not shown).

Animals and experimental procedure. - Experiments were carried out with 28 Wistar rat males and females weighing between $100-230 \mathrm{~g}$. They were housed under controlled environmental conditions $\left(22{ }^{\circ} \mathrm{C}, 60 \%\right.$ relative humidity, 10 12 hour dark period) and were fed a standard diet. Catheters were inserted into the two external jugular veins under chloral anaesthesia $(40 \mathrm{mg} / 100 \mathrm{~g}$, ip) according to the technique of Jarrige et al. (1978). Injections were performed into the right vein whereas blood was drawn from the left vein. In all experiments, zero time corresponded to ${ }^{125} \mathrm{I}$-glucagon injection.

Effects of native glucagon on uptake of radioactivity by liver and kidneys. In this study (10 rats), ${ }^{125} \mathrm{l}$-glucagon alone $(0.7 \mu \mathrm{Ci} / 100 \mathrm{~g}$ liveweight, i.e. $2 \mathrm{ng} / 100 \mathrm{~g})$ or mixed with increasing amounts of native glucagon $(50-50000 \mathrm{ng} / 100 \mathrm{~g})$ was injected at zero time. The rats were killed $4 \mathrm{~min}$ later by decapitation.

Time-course of liver and kidney radioactivity. Five rats received ${ }^{125} \mathrm{I}$-glucagon $(1.1 \mu \mathrm{Ci} / 100 \mathrm{~g}$ liveweight, i.e. $3 \mathrm{ng} / 100 \mathrm{~g})$ at zero time and were killed 1-30 min later. 
Time-course of plasma 125/-glucagon. In this experiment (13 rats), 125/glucagon $(1.2 \mu \mathrm{Ci} / 100 \mathrm{~g}$ liveweight, i.e. $4 \mathrm{ng} / 100 \mathrm{~g})$ was injected at zero time and blood was collected at 1, 2, 3.5 and 5 min after injection. To test the reversibility of glucagon uptake by tissues, some rats received an additional injection of an excess of native glucagon $(5000 \mathrm{ng} / 100 \mathrm{~g})$ at $0.3,0.7$ and $1.7 \mathrm{~min}$ after ${ }^{125}$. glucagon; the latter was injected at zero time.

Measurement of liver and kidney radioactivity. - After the rats were killed, the liver and kidneys were immediately removed, rinsed in saline, blotted and weighed. Whole kidneys and a piece of liver were counted for radioactivity.

Measurement of plasma ${ }^{125}$ /-glucagon. - Plasma ${ }^{125}$-glucagon was determined as described previously (Balage and Grizard, 1984). Briefly, blood samples were placed in heparinized tubes containing glucagon catabolism inhibitors (Bacitracin $0.1 \mathrm{mg} / \mathrm{ml}$; Aprotinin $1000 \mathrm{lU} / \mathrm{ml}$, Sigma Chemical Company, USA). The plasma was rapidly separated and stored in an ice bath until analysis. Plasma ${ }^{125}$ glucagon was determined after gel filtration of plasma into $50 \times 1 \mathrm{~cm}$ Biogel P 10 (BioRad Laboratory) columns. Elution was carried out under gravity at $+4{ }^{\circ} \mathrm{C}$ with $0.2 \mathrm{M}$ glycine buffer $(\mathrm{pH} 8.8)$. Fractions of $0.9 \mathrm{ml}$ were collected and counted for radioactivity.

Data analysis. - The results were expressed as the percentage of injected ${ }^{125}$ glucagon per $\mathrm{g}$ of liver, kidney or plasma. The decay curve of plasma 125/glucagon was plotted on a semi-logarithmic scale; the half-life of ${ }^{125}$-glucagon and the initial distribution space were estimated from the slope and ordinate intercept of the linear regression. Comparisons were performed by analysis of variance according to Snedecor and Cochran (1971).

\section{Results.}

\section{Plasma radioactivity.}

Plasma ${ }^{125}$-glucagon declined rapidly during the first 5 min after injection (fig. 1). As previously observed (Balage and Grizard, 1984), plasma radioactive material eluted mainly as 4 peaks (fig. 2) from the Biogel P 10 column. The first peak eluted in the void volume, the second in the elution volume of ${ }^{125}$-glucagon, the third in the volume corresponding to a molecular weight ranging from ${ }^{125}$ glucagon to ${ }^{125} \mathrm{I}-\mathrm{Na}$. The fourth peak eluted in a volume corresponding to ${ }^{125} \mathrm{I}-\mathrm{Na}$. Plasma ${ }^{125}$-glucagon decreased in a mono-exponential manner; indeed, when plotted on semi-logarithmic coordinates (fig. 1, inset) the decay curve became a straight line. The half-life and initial distribution space, estimated from the semilogarithmic plot of the plasma ${ }^{125}$-glucagon decay curve were $2.3 \mathrm{~min}$ and $22 \mathrm{ml} / 100 \mathrm{~g}$ liveweight; respectively. When labelled and unlabelled glucagon were sequentially injected in rats, there was a right shift in the plasma ${ }^{125}$-glucagon 
decay curve (fig. 1). It is important to note that this shift decreased progressively as the time between the ${ }^{125} \mathrm{~F}$-glucagon and native glucagon injections increased.

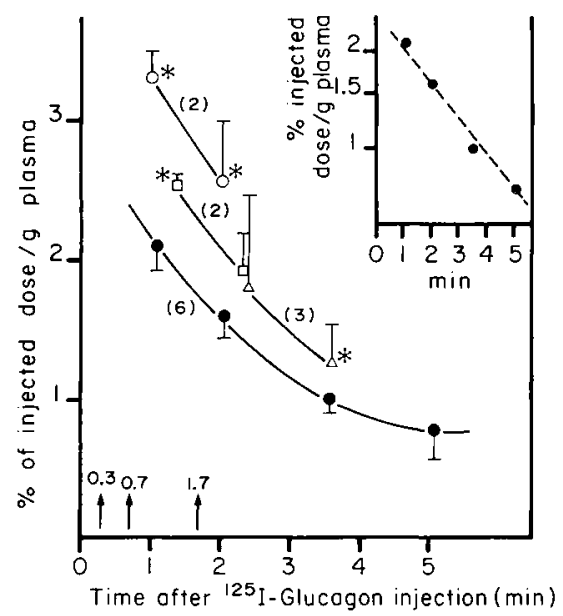

FIG. 1. - Plasma $125 /$-glucagon evolution after intravenous injection of $125 \%$ glucagon alone or after sequential injection of $125 /$ glucagon and excess unlabelled glucagon. Plasma 125 -glucagon concentration was determined after Biogel P-10 chromatography. At time zero, 125/-glucagon was injected as a bolus in all rats. The solid symbols (_- - - - represent plasma 1251 -glucagon evolution in rats that received $125 \mathrm{~F}$-glucagon alone. The open symbols represent plasma ${ }^{125}$-glucagon evolution in rats that received an excess of unlabelled glucagon at times indicated by the arrows, i.e. at $0.3(0-0), 0.7$ $(\square-\angle \square$ ) and $1.7 \mathrm{~min}(-\triangle-\triangle-\triangle-$ ) after 125 -glucagon injection. Each point is the mean $\pm S D$. The number of rats in each group is indicated in parentheses * indicates the plasma ${ }^{125} \mathrm{I}$-glucagon values in rats injected with an excess of native glucagon which were significantly higher $(P<0.05)$ than the corresponding values in rats injected with 125 -glucagon alone at the same time after 125 -glucagon injection. The inset represents the results form rats which received ${ }^{125} \mathrm{I}$-glucagon alone plotted on semilogarithmic coordinates.

FIG. 2. - Elution pattern of rat plasma. Plasma was filtered on Biogel P-10 column: fractions were collected by elution at $+4^{\circ} \mathrm{C}$ with $0.2 \mathrm{M}$ glycine buffer ( $\mathrm{pH} 8.8)$. The arrows indicate the void volume (Vo), the elution volume of standard labelled glucagon $\left({ }^{125} \mid\right.$-glu) and the elution volume of salts $\left(\mathrm{Na}^{125}\right)$. In the left panel, plasma was drawn $1 \mathrm{~min}$ after the injection of ${ }^{125}$-glucagon alone. In the right panel, plasma was drawn 1 min after $125 /$ glucagon injection and $0.7 \mathrm{~min}$ after excess native glucagon injection. The profiles shown correspond to a typical experiment.

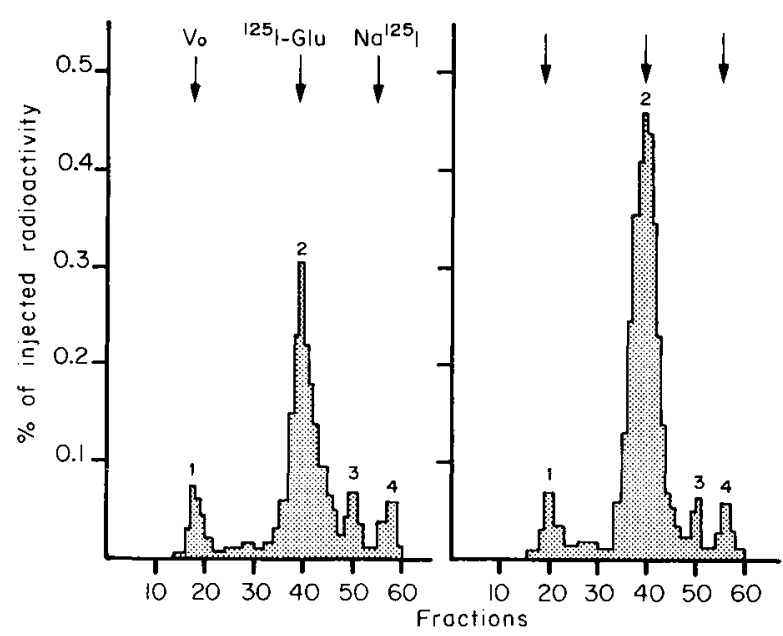

\section{Radioactivity in liver and kidneys.}

The radioactive material was largely associated with the liver and kidneys. However, the radioactivity uptake by liver and kidneys depended on two different processes : when radioactivity was associated to the liver, it exhibited a decay curve during the few minutes after injection (fig. 3) whereas it increased in the kidneys. Co-injection of native glucagon with ${ }^{125}$-glucagon resulted in a decrease in liver radioactivity (fig. 4) : the greater the amount of native glucagon, the lower the liver radioactivity. In contrast kidney radioactivity was unaffected by native glucagon levels. 


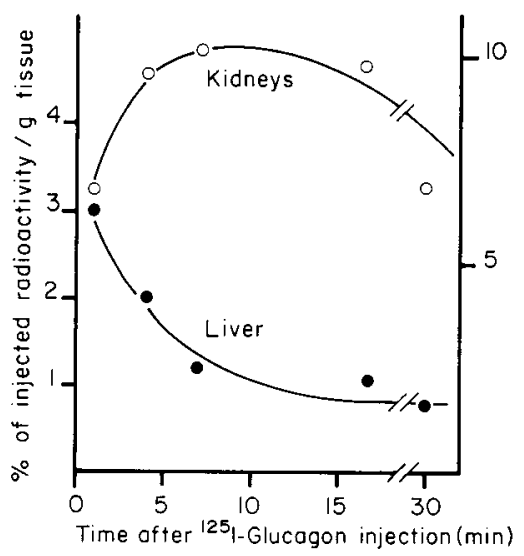

FIG. 3 - Time-course of liver and kidney radioactivity. At time zero 125 -glucagon was injected as a bolus into a jugular vein of the rat. Radioactivity of liver $(-1-)$ ) and kidneys $(-\mathrm{O}-\mathrm{O}-$ ) was measured at different time following the injection. Each point represents 1 rat.

FIG. 4 - Effect of native glucagon on radioactivity uptake by liver and kidneys. A single dose of 125/-glucagon was injected with or without increasing amounts of native glucagon as indicated. Four minutes after the I.V. injection, radioactivities of liver $(-1-)$ and kidneys (-O-O-) were measured. Each point is the mean $( \pm$ SD) of 2 rats.

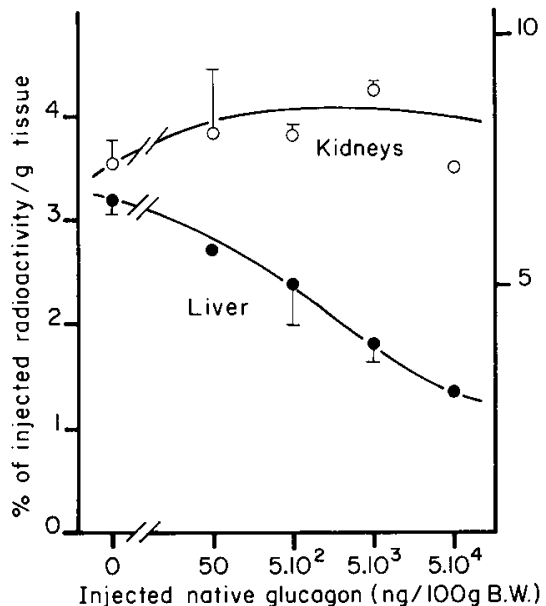

\section{Discussion.}

${ }^{125}$-glucagon, injected intravenously as a bolus in rats, was rapidly cleared from plasma with a half-life of approximately $2 \mathrm{~min}$ as previously observed (Balage and Grizard, 1984). It was associated largely with two organs, the liver and the kidneys, confirming that they are the primary sites of glucagon removal from the plasma (Jaspan et al., 1981 ; Ishida et al., 1983). Kidney uptake of glucagon was higher than liver uptake. Indeed kidney radioactivity increased during the first $5 \mathrm{~min}$ after injection whereas liver radioactivity decreased. In addition, the hepatic extraction ratio of glucagon was moderate (about $25 \%$ ), as previously observed in dogs (Jaspan et al., 1981). It was obtained by extrapolation to the ordinate intercept of the time-course of liver radioactivity uptake. In our experiment, liver uptake of glucagon was very rapid since maximum labeling occurred within $1 \mathrm{~min}$. It subsequently declined up to $5 \mathrm{~min}$ 
and was unchanged thereafter, in contrast with the data of Desbuquois and Postel-Vinay (1980). Indeed, in liver fractions from rats subjected to similar I.V. ${ }^{125}$-glucagon injection, maximum labeling occurred only 3-4 min after injection. This discrepancy may be explained by differences in methodology. Our experiment measured total radioactivity present in liver, i.e. radioactivity bound to liver components plus radioactivity in extracellular fluid, whereas Desbuquois and Postel-Vinay measured only the radioactive material associated with liver components. The exchanges between plasma and extracellular fluids are very rapid, particularly in the liver (Peters and Peters, 1972).

Four minutes after the simultaneous injection of ${ }^{125} \mathrm{I}$-glucagon and native glucagon, the total radioactivity associated with the liver decreased when increasing amounts of native glucagon were included. The curve of liver radioactivity is very similar to the inhibition-competition curves obtained in vitro during receptor studies. This similarity suggests that the process whereby the liver removes glucagon from plasma is saturable. Such a phenomenon has been previously demonstrated for insulin and glucagon (Sodoyez, Sodoyez-Goffaux and Moris, 1980a ; Desbuquois and Postel-Vinay, 1980) ; these authors reported a marked inhibition of liver uptake of radioactivity when a large excess of native hormone was coinjected with the labelled hormone. Desbuquois and Postel-Vinay, following the fate of radioactivity after ${ }^{125}$-glucagon injection in liver subcellular fractionations, clearly demonstrated that radioactivity rapidly associates with liver plasma membranes and progressively translocates within the cell to associate with the "Golgi " fractions. In addition, they showed that the radioactive material associated with "Golgi » retains its integrity as judged from rebinding assays. In view of these results, it is tempting to suggest that the labelled material associated with the liver was partly bound to receptors a few minutes after ${ }^{125}$-glucagon injection. Total radioactivity associated with the kidneys, however, did not decrease when increasing amounts of native glucagon were coinjected with ${ }^{125}$ glucagon. In constrast to the liver, the process whereby the hidneys remove glucagon from plasma is non-saturable, as previously observed with insulin (Sodoyez, Sodoyez-Goffaux and Moris, 1980a).

The sequential injection of labelled and unlabelled glucagon caused a shift to the right in the plasma ${ }^{125}$-glucagon decay curve. Such a phenomenon has been extensively described and analysed by Zeleznick and Roth (1978) and Sodoyez, Sodoyez-Goffaux and Moris (1980a). It could be related to the return of 125glucagon to the plasma compartment after release by the receptors (for example in liver). This no doubt involves only a part of the receptor compartment since measurements were carried out during the first 5 min after 125-l-glucagon injection. Such a period was too short to include total binding to liver receptors in view of their association kinetics (Barazzonne et al., 1980; Desbuquois and Postel-Vinay, 1980), indeed the distribution space of glucagon found from the plasma disappearance curve (i.e. $22 \mathrm{ml} / 100 \mathrm{~g}$ body weight) is too low to include the total liver receptor compartment. Alternatively, this phénomenon may also represent the displacement of ${ }^{125}$-glucagon from a non specific binding compartment or competition to uptake compartments. These types of phenomena have been observed in vitro (Cuatrecasas and Hollenberg, 1975). 
In conclusion it appears that shortly after injection, glucagon rapidly associates with the liver and kidneys according to two different precesses. In the liver, glucagon is trapped in a saturable compartment whereas in the kidneys, uptake is non-saturable. In addition, glucagon uptake by tissues seems to be reversible. As previously observed with insulin, the compartment where glucagon uptake occurs after I.V. injection has some fundamental properties (i.e. saturability and reversibility) similar to those shown in vitro in the glucagon receptors studied.

Reçu en avril 1985.

Accepté en octobre 1985.

Résumé. Relations entre le glucagon plasmatique et son prélèvement par les tissus chez le rat.

Le devenir du glucagon plasmatique a été étudié en détails par Desbuquois et PostelVinay. Le présent travail a été réalisé afin d'approfondir les relations entre la disparition plasmatique du glucagon et son prélèvement par les tissus. Pour cela nous avons effectué chez le rat, des injections intraveineuses de ${ }^{125}$-glucagon seul ou associé à des quantités variables de glucagon non radioactif. Le ${ }^{125}$-glucagon plasmatique est mesuré par la radioactivité éluée sous forme de glucagon à la suite du passage des plasmas à travers une colonne de Biogel $P_{10}$. La radioactivité captée par le foie et les reins a été mesurée. Le ${ }^{125}$ glucagon est rapidement éliminé du plasma selon une demi-vie voisine de $2 \mathrm{~min}$; il est rapidement capté par le foie et les reins. La radioactivité présente dans le foie diminue rapidement au cours des 5 premières minutes après l'injection alors que la radioactivité présente dans le rein augmente. L'injection simultanée de doses croissantes de glucagon non radioactif provoque une baisse progressive de la radioactivité associée au foie. Ceci indique que le prélèvement du glucagon par le foie est un processus saturable. En revanche, la radioactivité prélevée par le rein n'est pas modifiée. L'injection séquentielle de ${ }^{125}$-glucagon et d'une forte dose de glucagon non radioactif se traduit par un déplacement vers la droite de la courbe de disparition plasmatique du ${ }^{125}$-glucagon. Tout se passe comme si l'hormone non radioactive provoquait un retour de l'hormone radioactive dans le sang, suggérant que le prélèvement du glucagon par les tissus est un phénomène réversible. Ce travail montre donc que le glucagon se distribue in vivo dans un compartiment en partie réversible et saturable. Des propriétés identiques ont été mises en évidence in vitro pour les récepteurs spécifiques du glucagon.

\section{Références}

BALAGE M., GRIZARD J., 1984. Glucagon kinetics in growing rats fed different leveis of protein and/or energy. Reprod. Nutr. Develop., 24, 251-263.

BARAZZONE P., GORDEN P., CARPENTIER J. L., ORCI L., FREYCHET P., CANNIVET B., 1980. Binding, internalization and lysosomal association of ${ }^{125} /$-glucagon in isolated rat hepatocytes. A quantitative electron microscope autoradiography study. J. clin. Invest., 66, 1081-1093.

BATAILLE D., FREYCHET P., ROSSELIN G., 1974. Interactions of glucagon, gut glucagon, vasoactive intestinal polypeptide and secretin with liver and fat cell plasma membranes: binding to specific sites and stimulation of adenylate cyclase. Endocrinology, 95, 713-721.

BERGERON J. J. M., POSNER B. I., 1979. In vivo studies of the initial localization and fate of polypeptide hormone receptors by the technique of quantitative autoradiography. $J$. histochem. Cytochem. 27, 1512-1513.

CUATRECASAS P., 1971. Insulin-receptor interactions in adipose tissue cells : direct measurement and properties. Proc. nat. Acad. Sci. USA, 68, 1264-1268. 
CUATRECASAS P., DESBUQUOIS B., KRUG F., 1971. Insulin-receptor interactions in liver cell membranes. Biochem. Biophys. Res. Com., 44, 333-339.

CUATRECASAS P., HOLLENBERG M. B., 1975. Binding of insulin and other hormones to non-receptor materials: saturability specificity and apparent " negative cooperativity ». Biochem. Biophys. Res. Com., 62, 31-41.

DESBUQUOIS B., POSTEL-VINAY M. C., 1980. Receptor-mediated internalization of insulin, glucagon and growth hormone in intact rat liver. A biochemical study, 285-292. In BRANDENBURG D., WOLLMER A., Insulin. Chemistry, structure and function of insulin and related hormones W. de Gruyter, Berlin, New York.

FEHLMANN M., MORIN O., KITABGI P., FREYCHET P., 1981. Insulin and glucagon receptors of isolated rat hepatocytes : comparaison between hormone binding and amino acid transport stimulation. Endocrinology., 109, 253-261.

FREYCHET P., ROSSELIN G., RANCON F., FOUCHEREAU M., BROER Y., 1974. Interactions of insulin and glucagon with isolated rat liver cells. Binding of the hormones to specific receptors. Horm. Metab. Res., (suppl), 51, 72-78.

FREYCHET P., ROTH J., NEVILLE D. M., 1971. Monoiodo-insulin : demonstration of its biological activity and binding to fat cells and liver membranes. Biochem. Biophys. Res. Com., 43, 400408.

GAGLIARDINO J. J., PESSACQ M. T., TURYN D., DELLACHA J. M., 1980. Insulin binding to liver cells : a simple and useful in vivo model. Horm. Metab. Res., 12, 300-303.

GILL R. D., HART I. C., 1980. Properties of insulin and glucagon receptors on sheep hepatocytes : a comparison of hormone binding and plasma hormones and metabolites in lactating and non-lactating ewes. J. Endocrinol., 84, 237-247.

GIORGIO N. A., JOHNSON C. B., BLECHER M., 1974. Hormone receptors. Properties of glucagon binding proteins isolated from liver plasma membranes. J. biol. Chem., 249, 428-437.

ISHIDA T., LEWIS R. M., HARTLEY C. J., ENTMAN M. L., FIELD J. B., 1983. Comparison of hepatic extraction of insulin and glucagon in conscious and anesthetized dogs. Endocrinology, 112, 1098-1109.

JARRIGE J. F., BOUCHER D., LEINOT M., 1978. Catheterismes vasculaires chroniques chez le rat. Adaptation aux injections et prélèvements sanguins semi-continus pour études hormonales. C. R. Soc. Biol., 172, 919-926.

JASPAN J. B., POLONSKY K. S., LEWIS M., PENSLER J., PUGH W., MOOSSA A. R., RUBENSTEIN A. H., 1981. Hepatic metabolism of glucagon in the dog : contribution of the liver to overall metabolic disposal of glucagon. Am. J. Physiol., 240, E233-E244.

MORIN O., FEHLMANN M., FREYCHET P., 1982. Binding and action of insulin and glucagon in monolayer cultures and fresh suspensions of rat hepatocytes. Mol. cel. Endocrinol., 25. 339-352.

NOTTEY J. J., ROSSELIN G., 1971. Monoiodoglucagon : preparations, isolement identification, contrôle radio-immunologique. C.R. Acad. Sci. Paris, 273, 2118-2121.

PETERS T., PETERS J.C., 1972. The biosynthesis of rat serum albumin. Intracellular transport of albumin and rates of albumin and liver protein synthesis in vivo under physiological conditions. J. biol. Chem., 247, 3858-3863,

RODBELL M., BIRNBAUMER L., POHL S. L., SUNDBY F., 1971. The reaction of glucagon with its receptor: evidence for discrete regions of activity and binding in the glucagon molecule. Proc. nat. Acad. Sci. USA, 68, 909-913.

ROTH J., 1973. Peptide hormone binding to receptors: a review of direct studies in vitro. Metabolism, 22, 1059-1073.

SNEDECOR G. W., COCHRAN W. G., 1971. Methodes statistiques. ACTA (ed), Paris.

SODOYEZ J. C., SODOYEZ-GOFFAUX F., MORIS Y. M., 1980a. ${ }^{125}$ I-insulin : kinetics of interaction with its receptors and rate of degradation in vivo. Am. J. Physiol., 239, E3-E11.

SODOYEZ J. C., SODOYEZ-GOFFAUX F., THIRY-MORIS Y. M., 1980b. Kinetics of insulin binding to its receptors in vivo. Effects of fasting., 293-300. BRANDENBURG D., WOLLMER A., Insulin. Chemistry, structure and function of insulin and related hormones. W. de Gruyter, Berlin, New York.

ZELEZNICK A. J., ROTH J., 1978. Demonstration of the insulin receptor in vivo in rabbits and its possible role as a reservoir for the plasma hormone. J. clin. Invest., 61, 1363-1374. 